\title{
The Application of High Intensity Interval Training (HIIT) Method to the Increase of Aerobic Ability of Female Futsal Players
}

\author{
Yunita Sari*, Dikdik Zafar Sidik, Komarudin Komarudin \\ Department of Physical Education, Faculty of Graduate Studies \\ Universitas Pendidikan Indonesia \\ Bandung, Indonesia \\ *yunitasari8691@gmail.com
}

\begin{abstract}
Physical training is one of some important and decided factor in reaching the achievement. There are some method of training that can be used in increasing the abilities of physic. Futsal is the sport which need the prime physical ability. One of some components of futsal player physical ability as the beginning fundamental; is the endure (aerobik). The purpose of this research is in order to know the meaningful of the influence of HIIT training method application to the increasing of ability of aerobik. Population in this research is the unit of activity of female Indonesia Education University student for futsal is about 26 persons and sample that be taken is about 14 persons who be chosen as the needs of team. Sampling technical use purposive sampling technical. Research method use experiment method. Data collecting use bleep test for measuring the endure or aerobic of body. The statistic calculation use two average equivalent test. The result of research point out the average value of beginning test $(\overline{\mathbf{X}})$ is about 41,0 by deviation standard $(S)$ is about 6.4 and final test average value $(\overline{\mathrm{X}})$ is about 43,5 by deviation standard $(\mathrm{S})$ is about 3,50. Analysis result and data calculation tell whereas there is a significant influence for HIIT training method to the increasing of ability of aerobik.
\end{abstract}

Keywords-HIIT method; aerobic ability; bleep test

\section{INTRODUCTION}

There are seven peak achievement supporting both internally and externally, which is included into internal factor namely psychological, tactic /strategic, technic, physic, and body constitution. After that which is included into external namely system: condition competition and media also infrastructure of training and competition Sidik [1]. In order to realize the achievement of sport when athlete come into very important for elite component is physical training. Physical training is one of some important factors if want to get the maximal achievement in every item of sport [1]. To realize the achievement of item of sport when athlete come into very important component for elite level is physical training, in physical training there are so many physical component [2]. The physical abilities that exist in factual sport achievements are physiologically composed of anaerobic and aerobic abilities. Aerobic capacity is the ability to maintain high work output for long periods of time Cochram [3]. The max VO2 is also expressed as the total volume of oxygen used per minute ( $\mathrm{ml} / \mathrm{min})$ [4].

To improve the aerobic ability many practice methods are used. One of them is the method of High Intensity Interval Training or commonly called the HIIT. Interval training is a training system interspersed by intervals in the form of periods of rest [5]. HIIT can also be referred to as sprint interval training (SIT) whose implementation is above $100 \%$ vo 2 max [6]. Interval training involves repetition and recovery exercises [6,7]. Repetition on short duration (10-30s) of high intensity exercise interspersed with periods of active or passive recovery [8]. What needs to be considered in the interval training method is the distance or time taken, the speed or effort made, the number of repetitions of the work interval, the distance or the time of recovery, the type of recovery activity. Because of all these variables the execution is done consistently, as well as the recommended recovery period with active recovery [9]. In the recovery period the results of a known pulse at the beginning will be a benchmark for use as a break between reps. And knowing the recovery time after the end of repetition in the first set which then used as a benchmark to break between the next set [10].

Several studies show that acute (4 weeks) HIIT significantly improves the performance of a well-trained rower [11]. HIIT studies conducted on cyclists, swimmers and runners have reported significant improvements in Vo2max [12]. Then HIIT is an efficient time training method to increase aerobic capacity, speed and strength at the football club level of gaelic. Football [8].

\section{METHOD}

The research method used in this research is the experimental method with the design of One Group PretestPosttedesign [13]. The group of experiments is provided with the practice of High Intensity Interval Training. The treatment is given every day for 28 days. The research period was conducted from the beginning of March until the end of March 2017. The sample of this study amounted to 14 people using the technique of purposive sampling. 


\section{RESULTS AND DISCUSSION}

The results of this study know the impact of HIIT training methods on aerobic capabilities of female futsal athletes. The tests were performed using theatrical statistics through the tested sample t-test. The results can be seen in table 1 .

TABLE I HYPOTHESIS TEST RESULTS

\begin{tabular}{|c|c|l|c|c|}
\hline Variable & $\mathbf{t}$ & t table & Sig. & Decision \\
\hline Aerobik & 6,148 & 2,14 & 0,000 & Significant influence \\
\hline
\end{tabular}

The results of processing and data analysis, the result of changes in the ability improvement on each physical component seen changes in the average value obtained from the initial test 37.7 and the final test 40.5 it shows that the application of HIIT training methods significantly improve aerobic ability. This is supported by several theories that support interval training consisting of moderate intensity intensity exercise interspersed with periods of rest or reduced exercise intensity [7]. HIIT is a high intensity exercise aimed at describing intensities ranging from as low as $85 \%$ of maximal oxygen uptake (VO2 max or aerobic capacity) to $250 \%$ [6]. And interval training involves short and long repetitive exercises of intensity exercise interspersed with periods of recovery (light exercise or rest) [14].

So if someone has a good aerobic ability then at the time of doing the HIIT training method will not experience excessive fatigue and recovery will be faster [3].

In the study revealed that in the 9-11-year-old male and female climber, vo2max increased significantly in 5 weeks of HIIT and high-volume training (HVT) [15], increase in VO2max, threshold [16].

The criteria of aerobic performance results can be seen in table 2 .

TABLE II. AEROBIC CAPACITY RESUlTS

\begin{tabular}{|c|c|c|}
\hline Category & Total & VO2max \\
\hline Good (48-57) & 1 & A : 49.9 \\
\hline \multirow{13}{*}{ sufficient (37-47) } & \multirow{13}{*}{13} & $\mathrm{~A}: 47.7$ \\
\hline & & B : 57.1 \\
\hline & & $\mathrm{C}: 45.2$ \\
\hline & & $\mathrm{D}: 44.9$ \\
\hline & & $\mathrm{E}: 44.9$ \\
\hline & & $F: 44.2$ \\
\hline & & $\mathrm{G}: 43.3$ \\
\hline & & $\mathrm{H}: 42.2$ \\
\hline & & $\mathrm{I}: 41.5$ \\
\hline & & $\mathrm{J}: 40.8$ \\
\hline & & $\mathrm{K}: 39.9$ \\
\hline & & $\mathrm{L}: 39.2$ \\
\hline & & $\mathrm{M}: 37.5$ \\
\hline
\end{tabular}

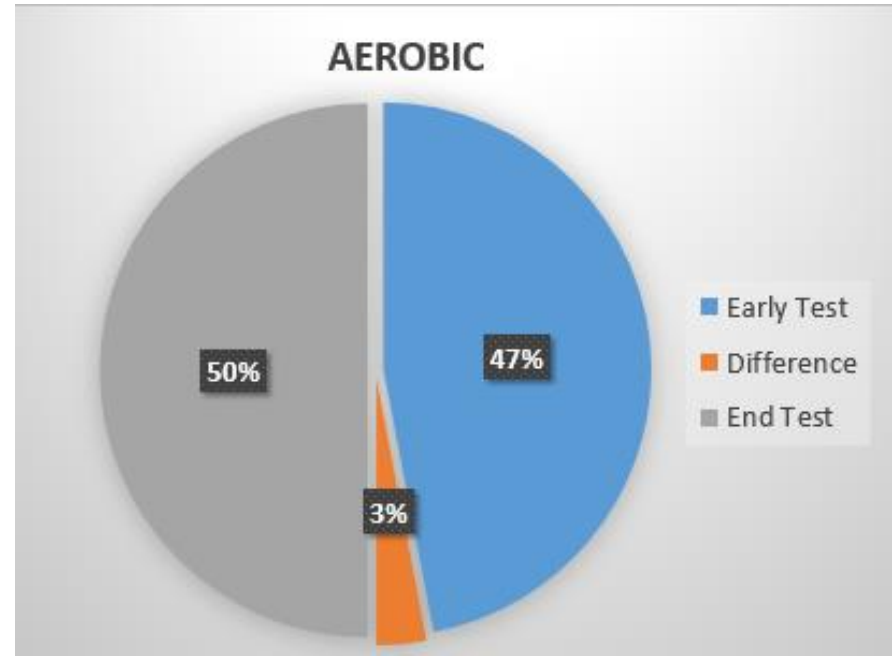

Fig. 1. Average comparison diagram of early test and aerobic end test.

\section{CONCLUSION}

Based on the results of research conducted then drawn the conclusion that there is a significant impact of HIIT training methods to increase the aerobic ability of female futsal athletes.

\section{REFERENCES}

[1] D.Z. Sidik, Pembinaan Kondisi Fisik. Buku Ajar FPOK Upi, p. 1., 2008.

[2] M. Buchheit, A. Mendez-villanueva, M. Quod, T. Quesnel and S. Ahmaidi "Improving Acceleration and Repeated Sprint Ability in WellTrained Adolescent Handball Players: Speed Versus Sprint Interval Training," 152-164, 2010.

[3] A. Cochram, "Interval training for the games player. Brian Mackenzie's Successful Coaching," (ISSN 1745-7513/ 33/ June), p. 5-7, 2006.

[4] G. Clara, D. Putri, and K. Nisa, Perbandingan Antara Vo 2 Maks Atlet Pria Cabang Olahraga Renang dan Lari Sprint Pada Persiapan Pekan Olahraga Provinsi di Bandar Lampung Comparison Between Vo 2 Max In Male Athlete Of Swim and Sprint Sport Branch At Preparation Of Province Sports Week, pp. 69-75, 2013.

[5] Harsono, Coaching dan Aspek-Aspek Psikologis Dalam Olahraga. Jakarta: Tambak Kusuma, 1998

[6] M.J. Smith, Sprint Interval Training - “ It 's a HIIT!"”, Training, (March), 2008.

[7] N.S. Jack Daniels, "Interval Training and Performance," July 1984, vol 1, no. 4, pp 327-334, 1984.

[8] J. Cathal, and Bs. Cregg, Effects of High Intensity Interval Training and High Volume Endurance Training on Maximal Aerobic Capacity, Speed and Power in Club Level Gaelic. (January), 2013.

[9] Gambetta, The Athletics congress's: Track and Field Coaching Manual (Second Edition). Champaign: Leisure Press, p. 96, 1989.

[10] A. Sumpena and D.Z. Sidik, "The Impact of Tabata Protocol to Increase the Anaerobic and Aerobic Capacity," IOP Conf. Series: Materials Science and Engineering vol. 1, no. 80, 2017.

[11] M.W. Driller, et al. "The effects of high-intensity interval training in well-trained rowers," International Journal of Sports Physiology and Performance, vol. 4, no. 1, pp. 110-121, 2009.

[12] C.D. Paton and W.G. Hopkins, "Effects of High-intensity Training on Performance and Physiology of Endurance Athletes," Sportscience, pp. 25-40, 2004.

[13] J.R. Freankel and N.E. Wellen, How to Design and Evaluate Research In Education. San Fransisco: State Univercity, 1990. 
[14] L.V. Billat, "Interval Training for Performance: A Scientific and Empirical Practice," Sports Medicine vol. 31, pp. 75-90, 2001.

[15] B. Sperlich, et al. "High-intensity interval training improves VO2peak, maximal lactate accumulation, time trial and competition performance in 9-11-year-old swimmers," European Journal of Applied Physiology, vol. 110, no. 5, pp. 1029-1036, 2010.
[16] J. Helgerud, et al. Aerobic endurance training improves soccer performance. Medicine and Science in Sports and Exercise, vol. 33, no. 11, pp. 1925-1931, 2001. 